\title{
Harassment at work? Empowerment and autonomy as coping strategies of young workers
}

\author{
Samantha Lemos Turte ${ }^{\mathrm{a}}{ }^{1}$, Maria Eduarda Cavadinha Correa ${ }^{\mathrm{b}}$, Andrea Aparecida da Luz ${ }^{\mathrm{a}}$ and Frida \\ Marina Fischer ${ }^{\mathrm{a}}$ \\ ${ }^{a}$ Department of Environmental Health, School of Public Health, University of São Paulo (USP), São Paulo, SP, \\ Brazil. \\ ${ }^{\mathrm{b}}$ Department of Maternal and Child Health, School of Public Health, University of São Paulo (USP), São Paulo, \\ SP, Brazil.
}

\begin{abstract}
There is a considerable number of researches about workplace violence, but few relate young workers and work harassment. This study aimed to investigate the reported perceptions of young apprentices and trainees about moral harassment at work and related coping strategies. Forty adolescent workers (22 men and 18 women) between 15 and 20 years old who received training by a non-governmental organization in São Paulo, Brazil, participated in the study. Data collection included individual and collective interviews. It was used an in-depth semi structured interview protocol. The discourses were analyzed using the hermeneutic-dialectic frame. Results showed that young workers reported little or no knowledge of strategies to cope with moral harassment at work, showing vulnerability to the effects of aggression. Effective coping strategies at work should embrace two important concepts of health promotion: empowerment and autonomy.
\end{abstract}

Keywords: Occupational health, workplace harassment, adolescent workers, mental health, health promotion.

\section{Introduction}

Violence is a phenomenon that is part of social relations and is responsible for several health problems. It consists of human actions of individuals, groups, classes, nations that affect physical, moral, mental or spiritual states or even cause death.

Violence at work includes both physical and psychological violence and it is a frequent precursor of mental illnesses, and to a lesser degree, physical injury among the workers. This kind of violence is variable, especially in non-industrialized countries. Psychological aggression is widespread across all sectors of employment and physical violence, although far less common, remains a significant problem. The job category, the nature of the work being performed, gender, age and experience are some of the factors that may influence to become a victim of this occupational hazard [1].Therefore, the workrelated mental illnesses due to violence at work are gaining visibility from quite a few studies, including those from the World Health Organization and International Labour Organization [2,11]. This growing concern with worker's health conducted to the concept of workplace harassment, which can cause or contribute to various mental and psychosomatic illnesses and behavior disorders.

Psychological harassment in organizations is defined as all those acts that repeatedly and persistently aimed to torment or frustrate a person, including repeated hostile verbal and nonverbal behaviors (excluding physical contact) which ultimately would provoke, frighten, intimidate, or bring discomfort to the victim. Also called workplace emotional abuse

\footnotetext{
${ }^{1}$ Corresponding author. Address: Faculdade de Saúde Pública/USP - Departamento de Saúde Ambiental - Av. Doutor Arnaldo, $715-2^{\circ}$ andar - CEP:01246-904, São Paulo,SP, Brasil. E-mail: samturte@usp.br. Phone: +55 1130617755
}

1051-9815/12/\$27.50 @ 2012 - IOS Press and the authors. All rights reserved 
[9], this concept is commonly used to describe all situations where a worker, supervisor, or manager is systematically mistreated and victimized by fellow workers, subordinates, or superiors. It is a systematic aggression and violence is targeted towards one or more individuals by one individual or by a group over a period of time [8]. Recent studies indicate that it is the psychological violence and harassment, rather than physical violence, that represent the greatest emotional threat to most workers [10].

Regarding teenagers who are discovering their places in the world of work, and beginning to assume multiple roles, inappropriate working conditions are associated with negative effects on their physical and mental well-being. The development of interpersonal competencies is an important step during adolescence [6] and it's important to be aware of what young workers should learn about work, supervision, and aggression. This is especially important since teenagers can be even more influenced by their work environments than adults do. The lessons learned during this socialization phase may help young workers to predict and cope with subsequent workplace aggression, and also be of support to prevent the escalation of more severe forms of aggression [3]

This study aimed to investigate the reported perceptions of young apprentices and trainees about moral harassment at work and related coping strategies.

\section{Methods}

\subsection{Data collection and Participants of the Study}

The field setting chosen for this study was a nongovernmental organization, established and run by an educational and nonprofit institution of São Paulo, Brazil. It works with groups of low income youngsters training them to become apprentices and trainees. Forty adolescents, 22 men and 18 women, with age brackets of 15 and 20 years old participated in this study. They entered the labor force at least six months prior the beginning of this investigation.

Data collection took place between November 2009 and August 2010. Individual interviews were carried out with 15 apprentices ( 9 men and 6 women) and 15 trainees (10 men and 5 women). Two collective interviews took place with a group of five apprentices each. An in-depth semi structured interview protocol was used either in individual as collective interviews. Interviews were recorded with a digital device and ranged from 20 to 80 minutes; textual transcription was then performed.

\subsection{Data analysis:}

Data were analyzed using the hermeneuticdialectic theoretical frame [4]. Such analysis involves a high degree of subjectivity and interpretative framework. The first step of analysis involved repeatedly reading of the transcripts, and resulted in key phrases. Along the coding process these key phrases were condensed to produce initial themes. The resulting sets of initial themes were examined to identify issues in common that were placed together producing a final category theme.

\section{Results}

Young workers mentioned difficulties to successfully avoid harassment at work: individual coping strategies showed that a major problem was the attitude that one must maintain to avoid the possibility of harassment. Some participants said they would "seek to solve the situation discussing with the harasser" or, instead, they would take the case to organization supervisors or coordinators of the educational institution where they attended once a week (as apprentices) or once a month (as trainees). Others reported they were aware of the legislation, rights and duties and were able to use that as a defense strategy. However, "to pretend nothing was happening" and "not to tell anyone" were frequently answered. Some youngsters said they did not know what to do if they had to deal with a case of bullying at work.

According to participants' reports, the main measures to be established by the organization could be: establishing spaces for dialogue, lectures, informal meetings and theatrical performances. They expect opportunities to freely express themselves without judgments or intimidation.

\section{Discussion and Conclusion}

Effective coping strategies should embrace two important concepts of health promotion: empowerment and autonomy. Empowerment is intrinsically linked to social participation. Empowerment relates to the recognition that individuals and communities 
have rights and are potentially capable of assuming the power to intervene and improve their living conditions [5]. Autonomy is another essential concept for promoting health and refers to a co-creation of greater capacity of individuals to understand and act upon themselves and the context in accordance with democratically established goals. Autonomy is built on interpersonal relationships through the dialectic of dealing with what I want and what the other wants. In other words, an autonomous person is co-responsible for both the constitution of self and his surrounding world. In order to make autonomy effective individuals must be able to handle the power system, operate with conflicts and establish commitments and contracts with other subjects to create well-being and a more democratic context [7]. In this sense, young workers must have access to knowledge of possible work-related psychosocial factors that may affect physical and mental health. Even though little is being said at work about workers' mental health, workers, as potential leaders, should also have opportunities for discussing ways of promoting mental health at work.

The participants of this study have reported little or no knowledge of possible strategies for coping with moral harassment at work, showing vulnerability to the effects of aggression. In our study it was revealed that those who had more knowledge of the law and the limits of professional relationships, and therefore were more empowered and autonomous, were able to deal more firmly with abusive situations.

Still, there isn't a specific legislation in Brazil about harassment at work. However, it is important to raise awareness about the problem, and implement effective actions to prevent psychological workplace violence. This would help adolescent workers to know about their rights and provide effective ways to deal with such situations.

\section{Acknowledgments}

Financial support: FAPESP (grant $n^{\circ} 2009 / 12515-0$ ); CNPq (473138/2008-5; 301605/2009-2).

\section{References}

[1] C. Mayhew, D. Chappell. Workplace violence: An overview of patterns of risk and the emotional/stress consequences on targets, International Journal of Law and Psychiatry 30 (2007), $327-339$.
[2] International Labour Organization. Mental health in the workplace, International Labour Office, Geneva, 2000.

[3] K.E. Dupré, M. Inness, C.E. Connelly, J. Barling, and C. Hoption. Workplace aggression in teenage part-time Employees, Journal of Applied Psychology, v. 91, n. 5 (2006), pp. 987997

[4] M.C.S. Minayo. O desafio do conhecimento: pesquisa qualitativa em saúde, Hucitec, São Paulo, 2008.

[5] M.F. Westphal. Promoção da saúde e prevenção de doenças, in: Tratado de Saúde Coletiva, Campos et al., eds., Hucitec, São Paulo, 2009, pp. 635-667.

[6] M.R. Frone. Interpersonal conflict at work and psychological outcomes: testing a model among young workers, Journal of Occupational Health Psychology, v.5, n.2 (2000), pp. 246-255

[7] R.T. Onocko Campos and G.W.S. Campos, Co-construção de autonomia: o sujeito em questão, in: Tratado de Saúde Coletiva, Campos et al., eds., Hucitec, São Paulo, 2009, pp. 669-688.

[8] S. Einarsen. Harassment and bullying at work: a review of the Scandinavian approach, Aggression and Violent Behavior, v. 5, n.4 (2000), pp. 379-401.

[9] S. Harvey, L. Keashly. Emotional abuse: how the concept sheds light on the understanding of psychological harassment (in Quebec), Pistes, v.7, n.3 (2007).

[10] V. Di Martino, H. Hoel, C.L. Cooper. Preventing violence and harassment in the workplace, European Foundation for the Improvement of Living and Working Conditions, Dublin, 2003

[11] World Health Organization. Raising awareness of psychological harassment at work. Protecting Workers' Health Series no. 4 G; Genève; 2003. 